\title{
ISOLASI DAN SELEKSI RIZOBAKTERI YANG BERPOTENSI SEBAGAI AGEN PENGENDALI PANTOEA STEWARTII subsp. STEWARTII PENYEBAB LAYU STEWART PADA TANAMAN JAGUNG
}

\author{
Haliatur Rahma ${ }^{1}$, Aprizal Zainal ${ }^{1}$, \& Suryati $^{2}$ \\ ${ }^{1}$ Program Studi Agroekoteknologi Fakultas Pertanian Universitas Andalas \\ ${ }^{2}$ Jurusan Kimia Fakultas Matematika dan Ilmu Pengetahuan Alam Universitas Andalas \\ Kampus Universitas Andalas Limau Manis Padang 25163 \\ Email: haliatur_rahma@yahoo.com
}

\begin{abstract}
Isolation and selection of rhizobacteria potentially as biocontrol agents against Pantoea stewartii subsp. stewartii causing stewart's wilt disease in maize. Group of bacteria that colonize plant roots were known as Plant Growth Promoting Rhizobacteria (PGPR), in addition to capable of suppressing the development of pathogens also has the ability to improve plant health. This study aims to isolate rhizobacteria from rhizosphere of maize in West Sumatera. Rhizobacteria were characterized and tested for its ability to suppress the bacteria Pantoea stewartii subsp. stewartii causes stewart wilt's disease on maize. In this research 15 isolates of rizobacteria potential as biological agent were found, i.e. 6 isolates of the fluorescens bacteria group, 5 isolates of non fluorescens bacteria group and 4 isolates of heat-resistant bacteria group.
\end{abstract}

Key words: fluorescens bacteria, non fluorsecens bacteria, heat-resistant bacteria, Pantoea stewartii subsp. stewartii, PGPR, rhizobacteria

\begin{abstract}
ABSTRAK
Isolasi dan seleksi rizobakteri yang berpotensi sebagai agen pengendali Pantoea stewartii subsp. stewartii penyebab layu stewart pada tanaman jagung. Kelompok bakteri yang mengkolonisasi perakaran tanaman dikenal sebagai Plant Growth Promoting Rhizobacteria (PGPR) selain mampu menekan perkembangan patogen juga memiliki kemampuan meningkatkan kesehatan tanaman. Penelitian ini bertujuan untuk mengisolasi rizobakteri pada daerah perakaran tanaman jagung di Kabupaten Padang Pariaman, Pesisir Selatan dan Pasaman Barat, selanjutnya dikarakterisasi dan diuji kemampuannya untuk menekan bakteri Pantoea stewartii subsp. stewartii penyebab penyakit layu stewart pada tanaman jagung. Hasil penelitian menunjukkan hanya 15 isolat rizobakteri yang berpotensi sebagai agen hayati, yaitu 6 isolat dari kelompok bakteri fluorescens, 5 isolat dari kelompok bakteri non fluorescens dan 4 isolat dari kelompok bakteri tahan panas.
\end{abstract}

Kata kunci: bakteri fluorescens, bakteri non fluorsecens, bakeri tahan panas, Pantoea stewartii subsp. stewartii, PGPR, rizobakteri

\section{PENDAHULUAN}

Salah satu penyebab terjadinya penurunan produksi pada tanaman budidaya adalah gangguan organisme penganggu tanaman (OPT) terutama dari kelompok patogen. Sesuai dengan program pertanian berkelanjutan yang diterapkan di Indonesia maka teknik pengendalian OPT harus mengacu pada Pengendalian Hama dan Penyakit secara Terpadu (PHT). Salah satu komponen utama dari program PHT adalah pengendalian hayati dengan memanfaatkan agen pengendalian hayati indigenus, yaitu pengendalian hayati menggunakan mikroorganisme yang berasosiasi secara alami dengan tanaman inang. Keuntungan penggunaan agen hayati indigenus antara lain ramah lingkungan, berkesinambungan, kesesuaian ekologis, dan dapat diintegrasikan dalam program PHT serta dapat diperbanyak dengan teknologi yang sederhana dan mudah cara aplikasinya. Di samping itu pengendalian hayati mempunyai potensi dapat melindungi tanaman selama siklus hidupnya, bahkan beberapa jenis mikroorganisme mampu menghasilkan hormon tumbuh (Garcia et al., 2003), memfiksasi N (Bai et al., 2003), dan melarutkan $\mathrm{P}$ (van Loon et al., 1998).

Sekelompok bakteri yang mengkolonisasi daerah perakaran tanaman yang dikenal sebagai Plant Growth 
Promoting Rhizobacteria (PGPR)/ Rizobakteri telah banyak dikembangkan untuk pengendalian penyakit tanaman, diantaranya adalah dari kelompok Pseudomonas fluorescens dan non fluorescens, bakteri tahan panas yang meliputi Bacillus, Clostridium, selanjutnya bakteri serta bakteri penghasil siderofor dan pendegradasi kitin (Baker \& Cook, 1974).

Penyakit layu stewart pada tanaman jagung disebabkan oleh patogen Pantoea stewartii subsp. stewartii. Patogen ini pertama kali ditemukan di Sumatera Barat dengan kejadian penyakit 1-15\% (Rahma \& Armansyah, 2008), Survey penyakit layu stewart di Bogor menunjukkan persentase kejadian penyakit 23,67-31,45\% (Rahma et al., 2014). Deteksi sampel tanaman jagung bergejala penyakit layu stewart dari Sumatera Barat, Sumatera Utara dan Lampung dengan teknik polymere chain reaction (PCR) menggunakan primer spesifik HRP 1d/HRP 3c menunjukkan bahwa sampel ini positif terinfeksi Pantoea stewartii subsp. stewartii.

Pengendalian penyakit layu stewart di luar negeri masih ditujukan terhadap serangga vektor, pengendalian yang ditujukan terhadap patogen penyebab belum banyak dilaporkan. Penyakit layu stewart termasuk penyakit baru di Indonesia, oleh karena itu pengendalian penyakit ini menjadi penting untuk mencegah terjadinya epidemi penyakit di lapangan. Pengendalian penyakit ini menggunakan bakteri endofit asal akar jagung, benih jagung dan akar rumput ternyata mampu menekan persentase keparahan penyakit dengan kisaran 48,95 $55,60 \%$ (Rahma et al., 2014). Namun menurut Rosenblueth \& Esperanza (2006) bakteri endofit mempunyai kepadatan populasi lebih rendah dibandingkan dengan bakteri rizosfer atau bakteri patogen, sehingga dibutuhkan alternatif pengendalian menggunakan rizobakteri yang memiliki populasi dan keragaman yang tinggi di bagian perakaran tanaman. Sejauh ini belum ada laporan pengendalian penyakit ini menggunakan rizobakteri.

Penelitian ini bertujuan untuk mengisolasi rizobakteri dari daerah perakaran tanaman jagung dari beberapa lokasi pertanaman jagung di Sumatera Barat dan seleksi rizobakteri yang mampu menekan pertumbuhan bakteri Pantoea stewartii subsp. stewartii penyebab penyakit layu stewart pada tanaman jagung.

\section{METODE PENELITIAN}

Tempat dan Waktu. Penelitian dilakukan di Laboratorium Pengendalian Hayati Program Studi Agroekoteknologi Fakultas Pertanian Universitas Andalas pada bulan Maret-September 2015.
Eksplorasi Isolat Rizobakteri. Rizobakteri diisolasi dari daerah rizosfer tanaman jagung di beberapa lokasi di Sumatera Barat (Pasaman Barat, Padang Pariaman dan Pesisir Selatan). Isolasi rizobakteri dilakukan dengan menggunakan metode pengenceran berseri. Sebanyak $10 \mathrm{~g}$ contoh tanah dari perakaran tanaman jagung diencerkan dengan $90 \mathrm{ml}$ air steril yang mengandung $0,85 \% \mathrm{NaCl}$ dalam tabung erlenmeyer $250 \mathrm{ml}$. Campuran dalam tabung erlenmeyer dikocok selama 2 jam menggunakan rotary shaker, kemudian dibuat pengenceran berseri hingga $10^{-7}$. Untuk mendapatkan koloni bakteri kelompok Pseudomonas berfluoresens sebanyak $100 \mu \mathrm{l}$ suspensi pengenceran $10^{-5}-10^{-7}$ disebar ke dalam cawan petri yang telah berisi media King'S B Agar (KBA) menggunakan glass beads steril. Untuk mendapatkan isolat bakteri kelompok Bacillus, suspensi dari pengenceran $10^{-3}$ dipanaskan dalam penangas air pada suhu $80{ }^{\circ} \mathrm{C}$ selama 30 menit (Kim et al., 2008), dilanjutkan pengenceran berseri hingga $10^{-7}$, sebanyak $100 \mu$ l suspensi disebar ke dalam cawan Petri yang telah berisi media tryptic soy agar (TSA) dan diratakan menggunakan glass beads steril, selanjutnya diinkubasi pada suhu ruang selama 48 jamPengamatan dilakukan terhadap koloni bakteri yang tumbuh pada masing-masing media. Koloni bakteri yang tumbuh pada media KBA diamati di bawah lampu ultraviolet untuk membedakan kelompok bakteri Pseudomonas berfluoresens dengan bakteri non fluorescens. Koloni bakteri dengan karakter berbeda yang tumbuh pada media TSA langsung dipindahkan pada media TSA baru hingga diperoleh biakan murni. Kemudian biakan murni tiap isolat yang diperoleh disimpan dalam gliserol $20 \%$ pada suhu $-20{ }^{\circ} \mathrm{C}$ untuk sebagai stok dan digunakan dalam tahap pengujian selanjutnya.

\section{Seleksi Isolat Rizobakteri dalam Menekan} Pertumbuhan Pantoea stewartii subsp. stewartii. Seluruh isolat rizobakteri yang diperoleh diseleksi berdasarkan hasil uji antibakteri terhadap Pantoea stewartii subsp. stewartii BGR28 (Pnss BGR28) (Rahma, 2013). Uji daya hambat terhadap Pnss BGR28 dilakukan untuk menyeleksi bakteri rizobakteri yang berpotensi sebagai bakteri antagonis. Pengujian dilakukan pada media TSA dengan metode Difusi Kertas Cakram-Agar (Madigan et al., 1997). Isolat Pnss BGR28 yang berumur 48 jam dengan kerapatan 4,5 x $10^{8} \mathrm{sel} / \mathrm{ml}$ skala $4 \mathrm{McF}$ arland (Klement et al., 1990) disebar sebanyak $100 \mu \mathrm{l}$, pada media TSA. Potongan kertas saring (diameter $1 \mathrm{~cm}$ ) yang telah direndam dalam larutan mengandung rizobakteri (dengan kerapatan 4,5 x $10^{8} \mathrm{sel} / \mathrm{ml}$ ) berumur 48 jam diletakkan di tengah cawan 
Petri. Kemudian biakan diinkubasi pada suhu kamar sampai 5 hari. Pengamatan dilakukan setiap hari dengan melihat pembentukan lingkaran zona bening di sekeliling kertas saring yang menandakan rizobakteri menghambat pertumbuhan (antibiosis) Pnss BGR28. Kemampuan antibiosis bakteri rizobakteri diamati secara deskriptif.

\section{Karakterisasi Isolat Rizobakteri}

Uji Pewarnaan Gram. Penentuan sifat Gram bakteri diuji dengan pewarnaan Gram. Koloni bakteri diambil secara aseptis menggunakan jarum ose dan dioleskanmerata di atas gelas objek yang telah ditetesi akuades. Kemudian difiksasi di atas lampu Bunsen, selanjutnya ditetesi dengan larutan crystal violet selama 1 menit. Larutan crystal violet dicuci dengan air mengalir dan dikeringkan. Selanjutnya sediaan bakteri ditetesi dengan larutan iodine selama 1 menit dan dicuci dengan air mengalir dan dikeringkan. Untuk menghilangkan zat warna ditambahkan alkohol selama 30 detik dengan memiringkan gelas objek. Terakhir ditetesi larutan safranin sekitar 15 detik untuk membedakan lebih jelas reaksi tipe Gram bakteri. Bakteri Gram positif akan menunjukkan warna biru kehitaman pekat karena menangkap warna crystal violet sebaliknya bakteri gram negatif berwarna merah (Goto, 1990).

Uji Endospora. Pengujian endospora dilakukan pada isolat bakteri tahan panas. Masing-masing isolat diambil secara aseptik dengan menggunakan jarum ose. Bakteri dioleskan secara merata pada gelas objek steril dan diberi akuades. Isolat bakteri difiksasi di atas nyala bunsen sampai kering. Preparat ditutup dengan kertas yang mudah menyerap air, kemudian diletakkan diatas air mendidih selanjutnya ditetesi larutan pewarna malachite green dan didiamkan selama lebih kurang 10 menit. Preparat selanjutnya dicuci dengan air mengalir selama 30 detik. Setelah dikeringanginkan selanjutnya ditetesi dengan larutan safranin dan didiamkan selama 1 menit kemudian dibilas dengan air mengalir dan dikeringanginkan. Preparat diamati di bawah mikroskop dengan pembesaran kuat. Sebagai indikasi terdapatnya endospora akan berwarna hijau, dan bagian sel yang tidak mengandung endospora akan berwarna merah terang (Madigan et al., 1997).

Uji Produksi Siderofor secara Kualitatif. Produksi siderofor dilakukan dengan menggunakan media Chrome Azurol Sulfonat (CAS) Agar berdasarkan Husen (2003). Tiap 11 media CAS Agar terdiri atas empat larutan dengan masing-masing komposisi sebagai berikut: Larutan (1) berupa larutan indicator Fe-CAS (komposisi: $10 \mathrm{ml} \mathrm{FeCl}_{3} \cdot 6 \mathrm{H}_{2} \mathrm{O} 1 \mathrm{mM}$ dilarutkan dalam $10 \mathrm{mM}$ HCL; $50 \mathrm{ml}$ larutan CAS (1,21 $\mathrm{mg} / \mathrm{ml}$ ) dan $40 \mathrm{ml}$ larutan hexadecyl-trimetylammonium bromide (HDTMA) 1,82 mg/ml). Larutan (2) merupakan larutan penyangga dibuat dengan melarutkan $30,40 \mathrm{~g}$ piperazine- $N, N$-bis [2-ethanesulfolfonic acid] (PIPES) ke dalam $750 \mathrm{ml}$ larutan garam $\left(3 \mathrm{~g} \mathrm{KH}_{2} \mathrm{PO}_{4}\right.$, $5 \mathrm{~g} \mathrm{NaCl}, 10 \mathrm{~g} \mathrm{NH}_{4} \mathrm{Cl}, 20 \mathrm{mM} \mathrm{MgSO}, 1 \mathrm{mM} \mathrm{CaCl}_{2}$ ). Akuades ditambahkan hingga volume larutan mencapai $800 \mathrm{ml}, \mathrm{pH}$ larutan kemudian diukur dan ditera dengan $\mathrm{KOH} 50 \%$ hingga mencapai $\mathrm{pH}$ 6,8. Selanjutnya sebanyak $20 \mathrm{~g}$ agar-agar ditambahkan ke dalam larutan sebelum disterilisasi. Larutan (3) mengandung $2 \mathrm{~g}$ glukosa, $2 \mathrm{~g}$ manitol dan elemen mikro yang terdiri dari $493 \mathrm{mg} \mathrm{MgSO} \cdot 7 \mathrm{H}_{2} \mathrm{O}, 11 \mathrm{mg} \mathrm{MnSO} \cdot \mathrm{H}_{2} \mathrm{O}, 1,4 \mathrm{mg}$ $\mathrm{H}_{3} \mathrm{BO}_{3}, 0,04 \mathrm{mg} \mathrm{CuSO} \mathrm{CH}_{4} \mathrm{O}, 1,2 \mathrm{mg} \mathrm{ZnSO} \mathrm{Z}_{4} \cdot 7 \mathrm{H}_{2} \mathrm{O}$, dan $1 \mathrm{mg} \mathrm{NaMoO} \cdot 2 \mathrm{H}_{2} \mathrm{O}$, seluruh komponen larutan 3 dilarutkan dalam $70 \mathrm{ml}$ akuades. Larutan (4) terdiri atas $30 \mathrm{ml} 10 \%(\mathrm{~b} / \mathrm{v})$ cassamino acid yang disterilisasi dengan menggunakan membran filter berukuran 0,45 $\mu \mathrm{m}$. Medium CAS dibuat dengan mencampurkan larutan 2 dan 4 pada suhu $50^{\circ} \mathrm{C}$ setelah disterilisasi, kemudian ditambahkan larutan 3 dan 1 secara perlahanlahan selanjutnya dilakukan homogenisasi dengan menggunakan batang magnet. Medium CAS memiliki warna hijau tua. Uji produksi siderofor dilakukan dengan menggoreskan bakteri yang telah diremajakan terlebih dahulu pada media CAS. Isolat yang mampu menghasilkan siderofor ditandai dengan munculnya warna orange disekitar koloni bakteri.

Uji Reaksi Hipersensitif pada Daun Tanaman Tembakau. Isolat rizobakteri dengan kerapatan $10^{8} \mathrm{cfu} /$ ml diinfiltrasikan ke bawah permukaan daun tembakau, pengamatan dilakukan terhadap waktu munculnya gejala pertama (jam) berupa munculnya luka nekrosis pada permukaan daun.

\section{HASIL DAN PEMBAHASAN}

Eksplorasi Isolat Rizobakteri. Hasil isolasi rizobakteri dari tiga wilayah pengambilan sampel diperoleh 179 isolat (Tabel 1). Isolasi bakteri rizobakteri dari Kabupaten Padang Pariaman diperoleh 64 isolat, Kabupaten Pesisir Selatan 65 isolat, sementara dari Kabupaten Pasaman Barat diperoleh 50 isolat. Rizobakteri yang berhasil diperoleh dibedakan berdasarkan atas tiga kelompok yaitu bakteri non fluorescens, fluorescens dan bakteri tahan panas. Bakteri nonfluorescens termasuk kelompok rizobakteri yang paling banyak diperoleh yaitu 74 isolat, bakteri fluorescens 67 isolat dan bakteri tahan panas 35 isolat. 
Dari ketiga lokasi pengambilan sampel, Kabupaten Pasaman Barat merupakan daerah penghasil jagung tertinggi di Sumatera Barat, budidaya tanaman jagung di daerah ini dilakukan secara intensif secara monokultur dan proses penanaman pada umumnya tidak diawali dengan pengolahan tanah, melainkan langsung menugal tanah beberapa sentimeter dari tunggul bekas penanaman musim sebelumnya. Sementara di wilayah Kabupaten Padang Pariaman dan Pesisir Selatan penanaman jagung tidak dilakukan secara intensif seperti di diawali dengan melakukan pengolahan tanah. Menurut Ehrmann \& Ritz (2014) sistem tanaman tumpang sari menunjang interaksi antara tanah dan tanaman, yang merupakan faktor kunci dalam dinamika hara, kompetisi antar tanaman dan ketahanan terhadap penyakit. Teknik ini didahului dengan pengolahan tanah sehingga mampu mempengaruhi ekologi komunitas (dinamika populasi, epidemiologi, dan peran mikroorganisme dan makroorganisme dalam tanah). Diduga kondisi inilah yang menyebabkan populasi rizobakteri di Kabupaten Pasaman Barat lebih rendah bila dibandingkan dengan Padang Pariaman dan Pesisir Selatan. Menurut Soesanto (2008), kelimpahan bakteri di daerah rizosfer sangat beragam dan antara satu wilayah dengan wilayah lainnya berbeda-beda. Perbedaaan kelimpahan bakteri dari wilayah yang berbeda dipengaruhi oleh adanya eksudat akar dan didukung dengan lingkungan di dalam tanah yang akan mempengaruhi interaksi organisme antara mikroba tanah, tanaman dan tanah. Menurut Sutariati \& Wahab (2010) keseimbangan antara tanah, tanaman, dan lingkungan yang masih terjaga dengan baik, akan meningkatkan populasi rizobakteri di daerah perakaran yang berperan sebagai biofertilizer dan mampu berperan optimal sebagai pendukung pertumbuhan dan perkembangan tanaman. Hal ini dapat ditemukan pada wilayah yang menerapkan sistem pertanian tradisional dan variasi rizobakteri yang diperoleh lebih banyak dibandingkan dengan wilayah yang menerapkan sistem pertanian lebih intensif.

\section{Seleksi Rizobakteri Menekan Pertumbuhan Pantoea stewartii subsp. stewartii. Isolasi rizobakteri dari} perakaran tanaman jagung berhasil diperoleh bakteri yang menunjukkan ciri-ciri koloni bulat, berwarna krem, tepi koloni berombak tidak beraturan, permukaan koloni timbul, koloni yang berpendar bila disinari dengan sinar UV dikelampokkan ke dalam kelompok bakteri berfluorescens, sementara yang tidak berpendar dikelompokkan ke dalam bakteri non fluorescens. Sementara dari kelompok bakteri tahan panas memiliki ciri-ciri koloni berwarna putih keruh, koloni bulat tidak beraturan dan tepi koloni bergerigi tidak beraturan.

Tabel 1. Jumlah isolat rizobakteri tanaman jagung dari berbagai lokasi pengambilan sampel di Sumatera Barat

\begin{tabular}{lcccc}
\hline \multirow{2}{*}{$\begin{array}{l}\text { Lokasi pengambilan sampel } \\
\text { (Desa/Kec./Kab.) }\end{array}$} & $\begin{array}{c}\text { Non } \\
\text { Fluorescens }\end{array}$ & Fluorescens & Tahan panas & $\begin{array}{c}\text { Jumlah } \\
\text { isolat }\end{array}$ \\
\cline { 2 - 5 } & 17 & 14 & 7 & 38 \\
Lubuk Alung Kab. Padang Pariaman & 13 & 5 & 8 & 26 \\
Sikabu Kab. Padang Pariamn & $\mathbf{3 0}$ & $\mathbf{1 9}$ & $\mathbf{1 5}$ & $\mathbf{6 4}$ \\
\hline Jumlah Isolat & 3 & 6 & 4 & 13 \\
\hline Balai Selasa Kab. Pesisir Selatan & 2 & 9 & 0 & 11 \\
Pasar Baru Kab. Pesisir Selatan & 4 & 8 & 4 & 16 \\
Kambang Pesisir Selatan & 0 & 4 & 3 & 7 \\
Pelangai Pesisir Selatan & 11 & 6 & 1 & 18 \\
Air Haji Pesisir Selatan & $\mathbf{1 6}$ & $\mathbf{3 3}$ & $\mathbf{1 2}$ & $\mathbf{6 5}$ \\
\hline Jumlah Isolat & 11 & 4 & 0 & 15 \\
\hline Ligkuang Aua Pasaman Barat & 2 & 3 & 2 & 7 \\
Aua Kuning, Pasaman & 3 & 4 & 1 & 8 \\
Kinali, Kinali Pasaman Barat & 4 & 1 & 3 & 8 \\
Koto Baru Luhak Nan Duo, Pasaman Barat & 7 & 3 & 2 & 12 \\
Kapar, Luhak Nan Duo Pasaman Barat & $\mathbf{2 7}$ & $\mathbf{1 5}$ & $\mathbf{8}$ & $\mathbf{5 0}$ \\
\hline Total Isolat & $\mathbf{7 4}$ & $\mathbf{6 7}$ & $\mathbf{3 5}$ & $\mathbf{1 7 9}$ \\
\hline Total Keseluruhan Isolat & & & & \\
\hline
\end{tabular}


Tidak semua rizobakteri yang diisolasi mampu menghasilkan zona bening ketika ditumbuhkan bersamasama dengan dengan bakteri Pantoea stewartii subsp. stewartii. Zona bening ini menandakan bahwa rizobakteri mampu menekan perkembangan Pantoea stewartii subsp. stewartii yang ada disekitar koloninya. Kemampuan rizobakteri menghasilkan zona bening bervariasi dari $0,1 \mathrm{~cm}$ hingga $1,5 \mathrm{~cm}$. Tabel 2 menunjukkan bahwa dari 49 isolat yang diuji terdapat 26 isolat rizobakteri yang memiliki kemampuan dalam menghambat pertumbuhan Pantoea stewartii subsp. stewartii, yaitu 11 isolat bakteri non fluorescens, 9 isolat bakteri fluorescens dan 6 isolat bakteri tahan panas. Menurut Cook \& Baker (1996), terjadinya kompetisi terhadap ruang dan nutrisi akan mempengaruhi kemampuan penghambatan dari bakteri. Dimana pada kompetisi terhadap nutrisi dapat membentuk struktur dormansi berupa endospora yang bersifat resisten pada kondisi lingkungan yang buruk. Kemampuan rizobakteri dalam menghambat pertumbuhan bakteri patogen disebabkan adanya senyawa aktif berupa antibiotik. Menurut Glick (1995) salah satu mekanisme rizobakteri sebagai agens biokontrol yang paling efektif dalam menghambat proliferasi patogen adalah menyintesis antibiotik.
Kemampuan rizobakteri menekan pertumbuhan patogen juga dipengaruhi oleh kemampuan rizobakteri dalam menghasilkan siderofor. Menurut Budzikiewicz (2001) produksi siderofor dihubungkan dengan kemampuan rizobakteri berkompetisi dalam perebutan unsur Fe dan menghambat pertumbuhan patogen dengan mengeluarkan senyawa antibiotik. Hasil penelitian ini juga menunjukkan bahwa rizobakteri yang mampu menekan pertumbuhan Pantoea stewartii subsp. stewartii juga menghasilkan siderofor (Tabel 2 dan Tabel 3). Keuntungan lain yang diperoleh dari bakteri penghasil siderofor yang dapat menghasilkan antibiotik adalah senyawa antibiotik tersebut dapat menghambat pertumbuhan patogen pada saat kontak lansung di daerah perakaran tanaman. Hasil pengujian ini menunjukkan bahwa isolat rizobakteri yang mampu menghambat pertumbuhan bakteri patogen Pantoea stewartii subsp. stewartii dapat dijadikan kandidat agens antagonis untuk pengendalian penyakit tersebut.

Karakterisasi Rizobakteri. Rizobakteri yang berpotensi menekan perkembangan bakteri patogen Pantoea stewartii subsp. stewartii kemudian dikarakterisasi berdasarkan reaksi gram, ada atau tidaknya endospora (untuk bakteri tahan panas) dan

Tabel 2. Hasil seleksi isolat rizobakteri tanaman jagung dalam menekan pertumbuhan bakteri Pantoea stewartii subsp. stewartii

\begin{tabular}{lclccc}
\hline $\begin{array}{l}\text { Bakteri Non } \\
\text { Fluorescens }\end{array}$ & Zona bening & $\begin{array}{c}\text { Bakteri } \\
\text { Fluorescens }\end{array}$ & Zona bening & Bakteri tahan panas & Zona bening \\
\hline LA1Ma6.1 & + & LA2MK5.2 & + & LA1Mb6.1 & - \\
LA1Ma6.2 & - & LA2MK6.3 & + & LA1Mb.7.2 & - \\
LA1Ma6.4 & - & LA2MK7.1 & - & LA2Mb6.1 & - \\
LA2Pa6.1 & - & LA2MK7.4 & - & LA2Mb 6.2 & + \\
LA2Pa7.2 & - & SK1MK5 & + & LA2Mb7.1 & ++ \\
LA2Ma5.1 & - & SK1MK6.2 & + & LA2Mb7.4 & - \\
SK1Ma7 & - & SK1MK7.3 & - & PN1b6.1 & - \\
SK2Pa6.2 & + & SK2MK6.1 & - & PN2b6.2 & - \\
PN2a 7.1 & ++ & SK2MK6.5 & - & PN2b6.4 & - \\
PN3a6.2 & ++ & SK2PK7.3 & - & PN5b7.2 & ++ \\
PN5a5.1 & +++ & PN1K6.1 & + & PSM1b 7.3 & + \\
PN5a5.2 & - & PN1K7.1 & - & PSM3b7.1 & ++ \\
PSM1a 5. & + & PN1K7.4 & - & PSM5b6.2 & + \\
PSM1a7.1 & + & PN2K5.1 & + & & \\
PSM3a5.1 & ++ & PN2K5.4 & ++ & & \\
PSM3a6.2 & ++ & PSM2K5. & ++ & & \\
PSM4a5.2 & ++ & PSM2K7.1 & - & & \\
PSM5a5.2 & ++ & PSM2K7.2 & ++ & & \\
\hline
\end{tabular}


Tabel 3. Hasil karakterisasi isolat rizobakteri dari akar tanaman jagung

\begin{tabular}{|c|c|c|c|c|c|}
\hline Kode isolat & Asal isolat & $\begin{array}{c}\text { Reaksi } \\
\text { gram }\end{array}$ & $\begin{array}{l}\text { Ada/tidaknya } \\
\text { endospora }\end{array}$ & $\begin{array}{c}\text { Uji } \\
\text { siderofor }\end{array}$ & $\begin{array}{c}\text { Reaksi } \\
\text { hipersensitif }\end{array}$ \\
\hline \multicolumn{6}{|c|}{ Kelompok fluorescen } \\
\hline LA2MK5.2 & P.Pariaman & - b) & $\mathrm{td}$ & + & -d) \\
\hline La2MKB6.3 & P.Pariaman & - & $\mathrm{td}$ & + & - \\
\hline SK1MK5 & P.Pariaman & - & $\mathrm{td}$ & - & - \\
\hline SK1MK6.2 & P.Pariaman & - & $\mathrm{td}$ & - & - \\
\hline PN1K6.1 & Pesisir Selatan & - & $\mathrm{td}$ & + & - \\
\hline PN2K5.1 & Pesisir Selatan & - & $\mathrm{td}$ & + & + \\
\hline PN2K5.4 & Pesisir Selatan & - & $\mathrm{td}$ & - & - \\
\hline PSM2K5. 2 & Pasaman Barat & - & $\mathrm{td}$ & + & + \\
\hline PSM2K7.2 & Pasaman Barat & - & $\mathrm{td}$ & - & + \\
\hline \multicolumn{6}{|c|}{ Kelompok nonfluorescens } \\
\hline LA1Ma6.1 & P.Pariaman & $++^{\mathrm{a})}$ & $\mathrm{td}$ & + & $+^{c)}$ \\
\hline SK2Pa6.2 & P.Pariaman & + & $\mathrm{td}$ & - & - \\
\hline PN2a 7.1 & Pesisir Selatan & + & $\mathrm{td}$ & - & + \\
\hline PN3a6.2 & Pesisir Selatan & + & $\mathrm{td}$ & + & + \\
\hline PN5a5.1 & Pesisir Selatan & + & $\mathrm{td}$ & + & + \\
\hline PN5b7.2 & Pesisir Selatan & + & $\mathrm{td}$ & + & - \\
\hline PSM1a 5.1 & Pasaman Barat & + & $\mathrm{td}$ & + & - \\
\hline PSM1a7.1 & Pasaman Barat & + & $\mathrm{td}$ & + & - \\
\hline PSM3a5.1 & Pasaman Barat & + & $\mathrm{td}$ & - & - \\
\hline PSM3a6.2 & Pasaman Barat & + & $\mathrm{td}$ & - & + \\
\hline PSM4a5.2 & Pasaman Barat & + & $\mathrm{td}$ & - & + \\
\hline PSM5a5.2 & Pasaman Barat & + & $\mathrm{td}$ & + & + \\
\hline \multicolumn{6}{|c|}{ Kelompok tahan panas } \\
\hline $\mathrm{LA} 2 \mathrm{Mb} 6.2$ & P.Pariaman & + & ada & - & - \\
\hline LA2Mb7.1 & P.Pariaman & + & ada & - & - \\
\hline PSM1b 7.3 & Pasaman Barat & + & ada & + & - \\
\hline PSM3b7.1 & Pasaman Barat & + & ada & + & - \\
\hline PSM5b6.2 & Pasaman Barat & + & tidak ada & + & + \\
\hline
\end{tabular}

reaksi hipersensitif pada tanaman tembakau. Dari hasil pengujian, seluruh bakteri kelompok fluorescens termasuk bakteri Gram negatif, sementara kelompok bakteri non fluorescens dan bakteri tahan panas termasuk kedalam kelompok bakteri Gram positif. Hasil uji reaksi hipersensitif menunjukkan bahwa 3 isolat dari kelompok bakteri fluorescens yaitu PN1K6.1 (Pesisir Selatan) dan PSM2K5.2 dan PSM2K7.2 (Pasaman Barat) menunjukkan hasil yang positif. Sementara kelompok bakteri non fluorescens yaitu: isolat PN2a7.1, PN3a6.2, PN5a5.1 (Pesisir Selatan), 3 isolat dari Pasaman Barat: PSM3a6.2, PSM4a5.2 dan PSM5a5.2 dan satu isolat dari kelompok bakteri tahan panas yaitu PSM5b6.2 menunjukkan hasil reaksi hipersensitif yang positif. Hal ini mengindikasikan bahwa isolat-isolat ini tidak layak untuk dijadikan sebagai calon agens biokontrol karena diduga bersifat patogen pada tanaman. Sementara isolat yang menunjukkan hasil reaksi hipersensitif negatif dapat dijadikan sebagai calon agens biokontrol pada tanaman jagung.

\section{SIMPULAN}

Penelitian ini telah berhasil mengisolasi rizobakteri dari daerah perakaran tanaman jagung di Sumatera Barat. Hanya 15 isolat yang layak dijadikan sebagai agens biokontrol yaitu: 6 isolat bakteri fluorescens, 5 isolat bakteri non fluorescens dan 1 isolat bakteri tahan panas. 


\section{SANWACANA}

Terima kasih kepada Direktorat Penelitian dan Pengabdian kepada Masyarakat, Kementerian Riset Teknologi dan Pendidikan Tinggi, atas bantuan biaya penelitian melalui Penelitian Hibah Bersaing Nomor: 030/ SP2H/PL/Dit.Litabmas/II/2015 Tanggal 5 Februari 2015.

\section{DAFTAR PUSTAKA}

Bai Y, Zhou X, \& Smith DL. 2003. Enhanced soybean plant growth resulting from coinoculation of Bacillus strains with Bradyrhizobium japonicum. Crop Sci. 43:1774-1781.

Baker KF \& Cook RJ. 1974. Biological Control of Plant Pathogens. W. H. Freeman \& Co., San Francisco.

Budzikiewicz H. 2001. Siderophore-antibiotic conjugates used as Trojan horses against Pseudomonas aeruginosa. Curr. Top. Med. Chem. 1(1): 7382.

Cook RJ \& Baker KF. 1996. Biological Control of Plant Patogen $2^{\text {nd }}$ Ed. Freeman and Co.San Fransisco.

Ehrmann J \& Ritz K. 2014. Plant: soil interaction in temperate multi-cropping production system. Plant Soil 376(1): 1-29.

Fahy PC \& Hayward AC. 1983. Media and methods for isolation and diagnostic test. In: Fahy PC \& Persley GJ (Eds.) Plant Bacterial Dieseases. A Diagnostic Guide. pp. 337-378. Academic Press.

Garcia JAL, Probanza A, Ramos B, \& Manero FJG. 2003. Effects of three plant growth-promoting rhizobacteria on the growth of seedlings of tomato and pepper in two differrent sterilized and nonsterilized peats. Arch. Agron. Soil Scie. 49(1): 119-127.

Glick BR. 1995. The enhancement of plant-growth by free-living bacteria. Can. J. Microbiol. 41(2): 109-117.

Goto M.1990. Fundamentals of Bacteria Plant Pathology. Academic Press, INC. San Diego, New York, Boston, London, Sydney, Tokyo, Toronto.
Husen E. 2003. Screening of soil bacteria for plant growth promotion activities in vitro. Indo. J. Agric. Sci. 4(1): 27-31.

Kim YS, Jang BR, Chung IM, Sang MK, Ku HM, Kim KD, \& Chun SC. 2008. Enhancement of biocontrol activity of antagonistic Chryseobacterium strain KJ1R5 by adding carbon sources against Phytophthora capsici. Plant Pathol. J. 24(2): 164-170.

Klement Z, Rudolph K, \& Sands DC. 1990. Methods in Phytopathology. Akademia Kiado, Budapest.

Madigan MT, Martinko JM, \& Parker J. 1997. Biology of Microorganisms. 8th ed. Prentice Hall College, London.

Rahma H. 2013. Penyakit Layu Stewart (Pantoea stewarii subsp. stewartii) Pada Tanaman Jagung dan Upaya Pengendaliannya.

Rahma H, Sinaga MS, Surahman M, \& Giyanto. 2014. First Report of Stewart's Wilt of Maize Cause by Pantoea stewartii subsp. stewartii in Bogor District Indonesia. J. ISSAAS 20(2): 131-141.

Rahma H \& Armansyah. 2008. Penyebaran Penyakit Stewart oleh Bakteri Pantoea stewartii Sebagai Penyakit Baru pada Tanaman Jagung (Zea Mays) Studi Kasus di Sumatera Barat. Penelitian Dosen Muda. DP2M DIKTI No 005/SP2H/PP/DP2M/ III/2008.

Rosenblueth M \& Esperanza MR. 2006. Bacterial endophytes and their interactions with hosts. Mol. Plant Microbe Interac. 19(8): 827-837

Soesanto L. 2008. Pengantar Pengendalian Hayati Penyakit Tanaman. PT Raja Rafindo Persada. Jakarta.

Sutariati GAK \& Wahab A. 2010. Isolasi dan uji kemampuan rizobakteri Indigenous sebagai agensia pengendali hayati penyakit pada tanaman cabai. J. Hort. 20(1): 86-95.

Van Loon LC, Bakker PAHM, \& Pieterse CMJ. 1998. Systemic resistance induced by rhizosphere bacteria. Ann. Rev. Phytopathol. 36: 453-483. 